\title{
Detection and Quantification of Rhizoctonia solani AG-1 IA, the Rice Sheath Blight Pathogen, in Rice Using Real-Time PCR
}

\author{
Ronald J. Sayler and Yinong Yang, Department of Plant Pathology, University of Arkansas, Fayetteville 72701
}

\begin{abstract}
Sayler, R. J., and Yang, Y. 2007. Detection and quantification of Rhizoctonia solani AG-1 IA, the rice sheath blight pathogen, in rice using real-time PCR. Plant Dis. 91:1663-1668.

Rhizoctonia solani Kühn is the causal organism of sheath blight, a major rice disease worldwide that severely impairs yield and quality. It is difficult to identify the pathogen in the early phase of the infection and to accurately quantify the fungal development based on visual inspection. Therefore, a rapid and reliable method is advantageous for the detection and quantification of the pathogen causing this important rice disease. In this study, a real-time, quantitative polymerase chain reaction (QPCR) assay was developed to detect and quantify $R$. solani AG-1 IA DNA from infected rice plants. A specific primer pair was designed based on the internal transcribed spacer region of the fungal ribosomal DNA. The specific detection of $R$. solani DNA was successful with quantities as low as $1 \mathrm{pg}$. The QPCR assay could be used for detecting the rice sheath blight pathogen, quantifying fungal aggressiveness, and evaluating the resistance level of rice cultivars.
\end{abstract}

Additional keywords: early detection, $R$. oryzae, $R$. oryzae sativa, $R$. solani AG-1 IB

Sheath blight of rice (Oryzae sativa L.) is one of the most economically important disease of rice and occurs wherever rice is grown (37), including the southern United States. This disease is caused by the soilborne pathogen Rhizoctonia solani Kühn, with the teleomorph Thanatephorus сисиmeris (A.B. Frank) Donk, belonging to anastomosis group 1 intraspecific group IA (AG-1 IA). Symptoms typically appear in the late tillering or early internode elongation growth stages and consist of circular, oblong, or ellipsoid green-gray, watersoaked spots about $1 \mathrm{~cm}$ long near the water line (28).

No major gene for resistance has been found for sheath blight; however, partial resistance was observed during a survey of 6,000 rice cultivars (16), and genes contributing to partial resistance have been identified (22). One disadvantage to polygenic or partial resistance, like that found to sheath blight, is the difficulty in selection of resistance genes (9). Although several efforts have been made to identify quantitative trait loci (QTLs) for resistance to sheath blight $(18,19,23)$, success has been limited. Cultural methods such as crop rotation, fertilizer management, plant

Corresponding author: Y. Yang

E-mail: yuy3@psu.edu

Current address of Y. Yang: Department of Plant Pathology, Pennsylvania State University, University Park 16802.

Accepted for publication 20 July 2007.

doi:10.1094/PDIS-91-12-1663

(C) 2007 The American Phytopathological Society spacing, and silica amendment have been shown to provide modest disease control $(6,26,27)$, but are insufficient for most of the susceptible semidwarf cultivars grown commercially. As a result, disease control is achieved primarily through fungicide application at the onset of disease. Rapid and accurate diagnosis of the disease is important if fungicide applications are to be efficacious as the timing of foliar fungicide applications is critical for achieving effective disease control. However, diagnosis of this disease by visual symptoms is difficult at the early stages of lesion development when sheath blight may be confused with sheath rot (Sclerotium oryzae) or lesions caused by the rice stem borer (Scirpophaga sp.). In addition, the use of fungicides may be limited in the future due to environmental concerns, expense, and the potential development of fungicideresistant pathogen populations. Early detection of this disease may allow growers to apply fungicides in the early phase of the disease to prevent the spread of the disease to a wider area requiring much greater application of fungicides.

Real-time, quantitative polymerase chain reaction (QPCR) has been used for rapid identification and quantification of numerous plant-pathogenic fungi $(4,5,8$, $11-15,24,34)$, viruses $(3,7,10)$, and bacteria $(2,21,29,30,36)$ from infected host tissue. Currently, rice breeders assess the severity of sheath blight visually in their efforts to select resistant cultivars and to identify QTLs for resistance $(18,19,22)$. Visual rating of sheath blight infection is subject to the bias of the individual investigator and this is particularly a problem when comparing studies performed by different investigators, such as in QTL mapping. The assessment of partial resistance to sheath blight is especially difficult due to the effects of environmental variability on disease pressure. Quantification of $R$. solani DNA in infected rice tissue by real-time PCR may be useful to researchers by providing an unbiased method for measuring pathogen growth in infected plants. In addition to the ability to quantify pathogen DNA, real-time PCR is faster than conventional PCR for pathogen detection because it does not require the analysis of amplicons on an agarose gel.

In this study, we report the development of a real-time PCR assay for the detection and quantification of $R$. solani AG-1 IA DNA from infected rice tissue. The internal transcribed spacer (ITS) regions from different groups of $R$. solani were compared and used for designing a pair of PCR primers that is specific for the AG-1 IA isolates, but not other AG groups of $R$. solani. We have demonstrated that the realtime PCR method is very specific and highly sensitive for detecting and quantifying the sheath blight pathogen in rice leaves.

\section{MATERIALS AND METHODS}

Fungal isolates and plant materials. The fungal species, host, geographic origin, isolate code, anastomosis group, and GenBank accession numbers of their 1828S ITS used in this study are listed in Table 1.

The cultivars of rice (Oryza sativa subsp. japonica) used in this study were Nipponbare and Jasmine 85. Nipponbare is susceptible to sheath blight, whereas Jasmine 85 is partially resistant.

Pathogen culture and inoculation. Rice plants were grown in a computercontrolled greenhouse at temperatures of approximately $28^{\circ} \mathrm{C}$ during the day and about $24^{\circ} \mathrm{C}$ at night to the early tillering stage. Pathogen inoculations were conducted with a detached leaf method for convenience (Y. Jia, personal communication). The second-youngest leaf of 2month-old plants were cut into $16-\mathrm{cm}$-long segments and the detached leaves were placed immediately in square petri dishes (245 $\mathrm{mm}^{2}$; Corning, Corning, NY) containing a 3 MM Whatman filter paper (225 $\mathrm{mm}^{2}$ ) moistened with $25 \mathrm{ml}$ of deionized $\mathrm{H}_{2} \mathrm{O}$. Treatment leaves were arranged in the petri dish in a randomized block design with petri dish as block. $R$. solani strain RR0140 was grown for 3 days at $25^{\circ} \mathrm{C}$ on 
Difco potato dextrose agar (PDA) supplemented with tetracycline at $15 \mathrm{mg} /$ liter to prevent bacterial contamination. A 0.7mm-diameter PDA plug was excised from the periphery of a 3-day-old actively growing culture with a 1-ml pipette tip. The plug was placed in the middle of the abaxial surface of the leaf segment with a sterile toothpick. Petri dishes with inoculated leaves were maintained on the bench at $22^{\circ} \mathrm{C}$ under continuous fluorescent light (10 to $20 \mathrm{EM}^{-2} \mathrm{~s}^{-1}$ ) for $72 \mathrm{~h}$. The entire lesion length was measured 3 days after inoculation. This inoculation method was used solely to facilitate the rapid generation of infected rice leaves for the development of the real-time PCR quantification assay. Analysis of variance of lesion length was performed using JMP software (5.1.2; SAS Institute Inc. Cary, NC). The standard error of the mean was calculated.

DNA extraction. Approximately 300 $\mathrm{mg}$ of fungal mycelia or infected leaf tissue was ground with liquid nitrogen and transferred into an Eppendorf tube containing $400 \mu \mathrm{l}$ of extraction buffer $(0.3 \mathrm{M}$ $\mathrm{NaCl}, 50 \mathrm{mM}$ TrisHCl, $\mathrm{pH}$ 7.5, $20 \mathrm{mM}$ EDTA, 2\% sarkosyl, 0.5\% sodium dodecyl sulfate, and $5 \mathrm{M}$ urea). Subsequently, phenol/chloroform at $400 \mu \mathrm{l}$ solution $(1: 1, \mathrm{pH}$ 8.0) was added. After vortexing for 10 min, samples were centrifuged for $5 \mathrm{~min}$ at $14,000 \mathrm{rpm}$. The supernatant was transferred into a new tube and $2 \mu \mathrm{l}$ of RNase at $10 \mathrm{mg} / \mathrm{ml}$ was added. The sample was vor- texed a few seconds and incubated at $37^{\circ} \mathrm{C}$ for $1 \mathrm{~h}$. The DNA was precipitated with 0.7 volumes of isopropanol followed by centrifugation for $5 \mathrm{~min}$ at $14,000 \mathrm{rpm}$. Precipitated DNA was washed with $70 \%$ ethanol, air dried, and dissolved in $100 \mu \mathrm{l}$ of Tris (10 mM)-EDTA (1 mM). DNA concentration was determined on a NanoDrop ND-1000 spectrophotometer (NanoDrop Technologies Inc., Wilmington, DE).

Primer design. PCR primers specific for $R$. solani AG-1 IA were selected by the comparison of sequence alignments from the $18-28 \mathrm{~S}$ ribosomal (r)DNA ITS region of $17 R$. solani, four $R$. oryzae, and two $R$. oryzae sativa isolates (Table 1 ). Sequence alignments were performed with Vector NTI 6 software (Informax, North Bethesda, MD). Based on this analysis, the following pair of specific primers was designed for real-time PCR: forward primer Rs1F (65 to 92), 5'-GCCTTT TCTACCTTAATTTGGCAG-3' and reverse primer Rs2R (202 to 234) 5'-GTGTGTAAATTAAGTAGACAGCAA ATG-3'. Primer sequences were verified to have low homodimer and heterodimer potential as well as a low probability of forming a hairpin loop, using the OligoAnalyzer 3.0 web software (IDT, Coralville, IA). These primers amplified a fragment of 137 to $140 \mathrm{bp}$ suitable for both conventional and real-time PCR detection. Fragment size varied from 137 to $140 \mathrm{bp}$, as determined by DNA sequence analysis, depending on the specific isolates tested. The specificity of Rs1F and Rs2R was tested against the DNA of $R$. solani isolates from anastomosis groups AG 1-IA (rice), 1-IB (bean), 2, 4, 7, 8, and 11, as well as $R$. oryzae and $R$. oryzae sativa, using conventional PCR. PCR fragments were separated on a $1.5 \%$ agarose gel and stained with ethidium bromide.

Primers specific to the rice ubiquitin gene (accession number AF184279) were used to assess the quality of extracted DNA, allow the comparison DNA amount measured spectrophotometrically to the cycle threshold $(\mathrm{Ct})$ values, and allow the potential for relative QPCR. Ubiquitin primer sequences were as follows: RUBQF 5'-GTG GCC AGT AAG TCC TCA GC and RUBQR 5'-GAA ACG GGA CAC GAC CAA GG (35). The inclusion of the rice ubiquitin primers allows the potential for relative quantification as well as absolute $R$. solani DNA quantification.

Real-time PCR assay. Real-time PCR was performed with a Thermo-Fast 96well reaction plate and Thermo-Fast Caps (ABgene, Epsom, Surry, UK) in the Mx3000P real-time PCR machine from Stratagene Corporation (La Jolla, CA). Each well contains a $25-\mu 1$ reaction mixture that includes $12.5 \mu \mathrm{l}$ of $2 \times$ SYBR Green PCR Master Mix (Qiagen, Valencia, CA) and $12.5 \mu \mathrm{l}$ of primer (1 pmole of each forward and reverse primer). Extracted DNA $(1 \mu \mathrm{l})$ at $100 \mathrm{ng} / \mu \mathrm{l}$ was added

Table 1. Rhizoctonia spp. referenced in this study ${ }^{\mathrm{a}}$

\begin{tabular}{|c|c|c|c|c|c|}
\hline Genus species & Host & Origin & Isolate code & AG subgroup & Accession number \\
\hline Rhizoctonia solani & Oryza sativa, rice & Arkansas & RR0135 & AG-1 IA & AY185115 \\
\hline R. solani & Rice & Arkansas & RR0134 & AG-1 IA & AY185114 \\
\hline R. solani & Rice & Arkansas & RR0129 & AG-1 IA & AY185113 \\
\hline R. solani & Rice & Arkansas & RR0107 & AG-1 IA & AY185108 \\
\hline R. solani & Rice & Arkansas & RR0103 & AG-1 IA & AY185106 \\
\hline R. solani & Rice & Arkansas & RR0101 & AG-1 IA & AY185104 \\
\hline R. solani & Rice & Arkansas & RR0102 & AG-1 IA & AY185105 \\
\hline R. solani & Rice & Arkansas & RR0113 & AG-1 IA & AY185109 \\
\hline R. solani & Rice & Ivory Coast & T62 & AG-1 IA & AJ000200 \\
\hline R. solani & Rice & Vietnam & T5 & AG-1 IA & AJ000199 \\
\hline R. solani & Rice & Philippines & T68 & AG-1 IA & AJ000197 \\
\hline R. solani & Lolium multiflorum & Japan & na & AG-1 IA & AB122134 \\
\hline R. solani & Phaseolus vulgaris & Nebraska & PR5 & AG-1 IB & AF308629 \\
\hline R. solani & na & na & na & AG-1 IB & AB122136 \\
\hline R. solani & na & na & na & AG-1 IB & $\mathrm{AB} 122140$ \\
\hline R. solani & na & Brazil & AIC & AG-1 IC & AY154300 \\
\hline R. solani & Solanum tuberosum & Alaska & AG-2 1 & AG-2 1 & na \\
\hline R. solani & Gossypium hirsutum & Arkansas & AG-4 & AG-4 & na \\
\hline R. solani & G. hirsutum & Arkansas & AG-7 & AG-7 & na \\
\hline R. solani & Hordeum distychum & Washington & AG-8 & AG-8 & na \\
\hline R. solani & Soil & Arkansas & AG-11 & AG-11 & na \\
\hline R. solani & Leaf litter & Australia & WDa & AG-12 & AF153807 \\
\hline R. oryzae & Rice & Japan & na & na & AJ000195 \\
\hline R. oryzae & Rice & Japan & na & na & AJ000196 \\
\hline R. oryzae & Rice & Arkansas & HP1P42A & na & na \\
\hline R. oryzae & Rice & Arkansas & 1 & na & na \\
\hline R. oryzae & Rice & Arkansas & 2 & na & na \\
\hline R. oryzae & Rice & Arkansas & 4 & na & na \\
\hline R. oryzae sativae & Rice & Arkansas & na & na & na \\
\hline R. oryzae sativae & Rice & Côte d'Ivoire & $\mathrm{C} 2$ & na & AJ000191 \\
\hline R. oryzae sativae & Rice & West Malaysia & $\mathrm{C} 1$ & na & AJ000192 \\
\hline R. oryzae sativae & Rice & Japan & C3 & na & AJ000193 \\
\hline R. oryzae sativae & Rice & Japan & C6 & na & AJ000194 \\
\hline
\end{tabular}

a Abbreviation: na $=$ not available. 
to the reaction mix. Every DNA sample was analyzed with duplicate real-time PCR reactions. Amplification of extracted $R$. solani DNA was performed under the following conditions: (i) $95^{\circ} \mathrm{C}$ for $15 \mathrm{~min}$; (ii) 40 cycles of $95^{\circ} \mathrm{C}$ for $15 \mathrm{~s}, 60^{\circ} \mathrm{C}$ annealing for $30 \mathrm{~s}$, and $72^{\circ} \mathrm{C}$ extension for $15 \mathrm{~s}$; (iii) $95^{\circ} \mathrm{C}$ for $1 \mathrm{~min}$; and (iv) $55^{\circ} \mathrm{C}$ for $30 \mathrm{~s}$. The annealing temperature was lowered to $52^{\circ} \mathrm{C}$ when using both the $R$. solani primers Rs1F and Rs $2 \mathrm{R}$ and the rice ubiquitin primers RUBQF and RUBQR on samples during the same run. Absolute QPCR was employed to determine the quantities of $R$. solani DNA in detached rice leaves. A subset of 10-fold dilution series of $R$. solani DNA (100 ng, $10 \mathrm{ng}, 1 \mathrm{ng}, 100 \mathrm{pg}, 10$ $\mathrm{pg}$, and $1 \mathrm{pg}$ ) from a pure culture was analyzed in each absolute QPCR assay in duplicate to generate a standard curve. A real-time PCR assay typically was performed with three biological replications. The standard error of the mean was calculated accordingly. In addition to the data presented in this study, the assay has been tested successfully with different tissues of $R$. solani-infected rice plants from several other experiments.

\section{RESULTS}

Selection and testing of primer specificity. A nucleotide sequence comparison of the 18-28S rDNA ITS region revealed significant differences between $R$. solani AG-1 IA, $R$. solani from other intraspecific groups within AG-1, other AG groups, $R$. oryzae, and $R$. oryzae sativa. Based on these differences in sequence, PCR primers Rs1F and Rs $2 R$ were designed to be specific to the ITS of $R$. solani AG-1 IA isolates (Fig. 1). Primer sequences Rs1F and Rs2R matched all $R$. solani AG-1 IA sequences shown in Figure 1, as well as numerous ITS sequences of AG-1 IA isolates in the National Center for Biotechnology Information GenBank database identified using the Basic Local Alignment Search Tool (BLAST; 1). These primer sequences did not match the sequences of $R$. solani AG-1 IB (accession numbers
AF308629, AB122136, and AB122140), AG-1 IC (accession number AY154300), $R$. oryzae, or R. oryzae sativa (Fig. 1).

The specificity of Rs1F and Rs $2 \mathrm{R}$ was tested against the DNA of $R$. solani isolates from anastomosis groups AG 1-IA (rice), 1-IB (bean), 2, 4, 7, 8, and 11, as well as $R$. oryzae and $R$. oryzae sativa. The specific PCR fragment was amplified from the DNAs of three AG-1 IA isolates but not from the DNA of other $R$. solani AG groups, $R$. oryzae, or $R$. oryzae sativa (Fig. $2)$. The predicted diagnostic amplicon generated by conventional PCR of $R$. solani AG-1 IA isolates ranged in size from 137 to $140 \mathrm{bp}$ depending on the isolate tested.

Sensitivity of real-time PCR assay. To determine the assay sensitivity, DNA from $R$. solani AG 1-IA was used to prepare 10fold serial dilutions from $100 \mathrm{ng} / \mu \mathrm{l}$ to 1 $\mathrm{pg} / \mu \mathrm{l}$. Dilution of known quantities of purified $R$. solani AG-1 IA DNA revealed that as little as $1 \mathrm{pg}$ can be readily detected by real-time PCR (Fig. 3A). Although the
R. solani Soy AY270013

R. solani 135 AY185115

R. Solani 134 AY185114

R. Solani 129 AY185113

R. Solani 108 AY185109

R. Solani 107 AY185108

R. Solani 103 AY185106

R. Solani 102 AY185105

$R$. solani 101 AY185104

R. Solani T62 AJ000200

R. Solani T5 AJ000199

R. solani T68 AJ000197

$R$. solani PR5 AF308629

R. Solani AB122136

R. solani AB122140

R. Solani AIC AY154300

R. Solani Wda AF153807

$R$. oryzae AJ000196

R. oryzae-sativa AJ000194

R. solani Soy AY270013

R. Solani 135 AY185115

R. Solani 134 AY185114

R. Solani 129 AY185113

$R$. Solani 113 AY185109

R. solani 107 AY185108

R. Solani 103 AY185106

$R$. solani 102 AY185105

R. Solani 101 AY185104

R. Solani T62 AJ000200

R. solani T5 AJ000199

R. solani T68 AJ000197

R. Solani PR5 AF308629

$R$. solani AB122136

R. solani AB122140

R. solani AIC AY154300

R. Solani Wda AF153807

R. oryzae AJ000196

R. oryzae-sativa AJ000194

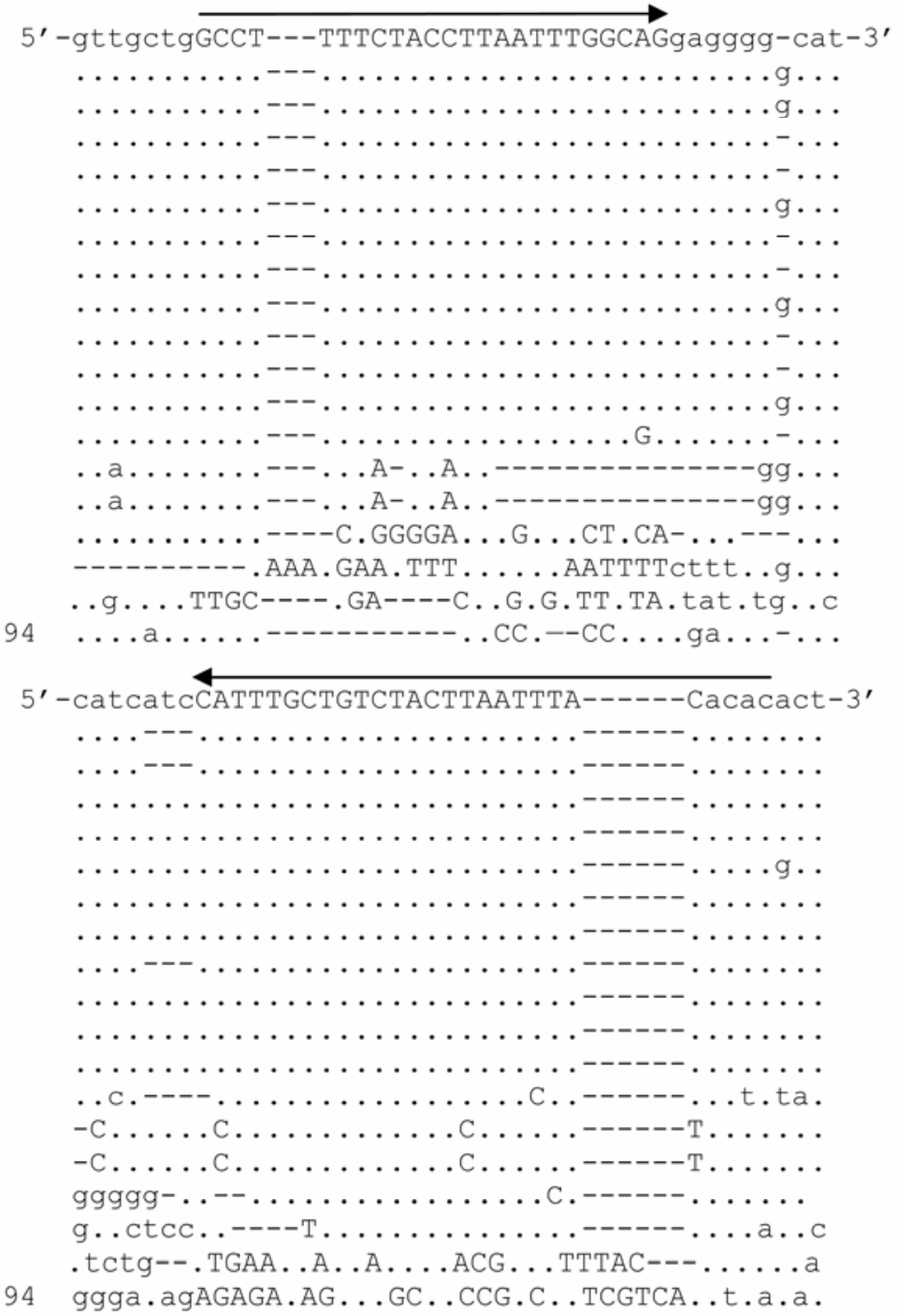

$5^{\prime}$-gttgctgGCCT---TTTCTACCTTAATTTGGCAGgagggg-cat-3'

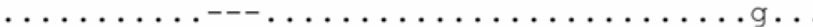

$\ldots \ldots, \ldots, \ldots, \ldots, \ldots$

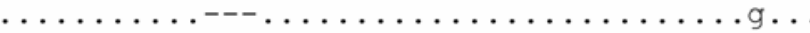

正,

$\ldots \ldots \ldots \ldots \ldots \ldots \ldots \ldots \ldots \ldots \ldots \ldots, \ldots$

$\ldots \ldots \ldots \ldots$. $^{---C}$. GGGGA . . G. . . CT.CA- ..-- .

. . AAA. GAA.TTT.......AATTTTCttt..g. .

.g....TTGC----.GA----C..G.G.TT.TA.tat.tg..C

'-catcatcCATTTGCTGTCTACTTAATTTA------Cacacact-3'

$\ldots \ldots \ldots \ldots \ldots \ldots \ldots$

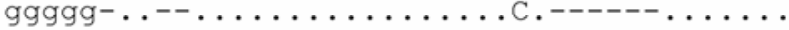

.. ctcc..----Т...........----......

ggga.agAGAGA.AG...GC..CCG.C. .TCGTCA..t.a.a.

Fig. 1. DNA sequence comparison of the ribosomal (r)DNA internal transcribed spacer (ITS) region of Rhizoctonia solani, $R$. oryzae, and $R$. oryzae sativa along with their GenBank accession numbers. Arrows indicate forward and reverse primers selected in this study for conventional and real-time polymerase chain reaction. The sequence of $R$. solani rDNA ITS regions begins at base 60 and finishes at base 212 . 
no-template control (NTC) was detected at a Ct of approximately 37 (Fig. 3A), analysis of the disassociation curve revealed that the amplification was due to primer dimer (data not shown). The disassociation temperature of the NTC amplicon was much lower than the experimental samples, consistent with an amplicon produced by primer dimer. A negative linear relationship was found between $\mathrm{Ct}$ value and the $\log$ of diluted pathogen DNA $\left(R^{2}=\right.$ 0.9911). The technical variation of the QPCR assay was low when using purified $R$. solani DNA (Fig. 3B). R. solani DNA was quantifiable from $1 \mathrm{pg}$ to $100 \mathrm{ng}$ (Fig. 3B). It may be possible to detect less than

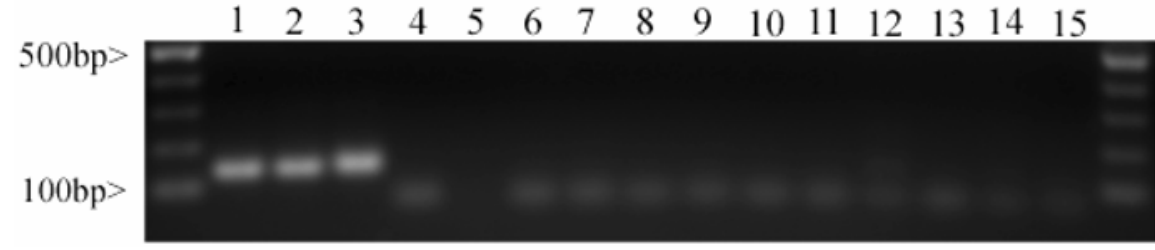

Fig. 2. Primer specificity test for Rhizoctonia solani anastomosis group 1 (AG-1) intraspecific group IA. Lane $1, R$. solani RR0102; lane 2, $R$. solani RR0113; lane 3, $R$. solani RR0107; lane 4, $R$. solani AG-1 intraspecific group IB; lane 5, $R$. solani AG-2 1; lane 6, $R$. solani AG-4; lane 7, $R$. solani AG-7; lane $8, R$. solani AG-8; lane 9, $R$. solani AG-11; lane $10, R$. oryzae HP1P42A; lane $11, R$. oryzae sati$v a$; lane $12, R$. oryzae \#1; lane 13, R. oryzae \#2; lane 14, R. oryzae \#4; and lane 15 , negative control.

A

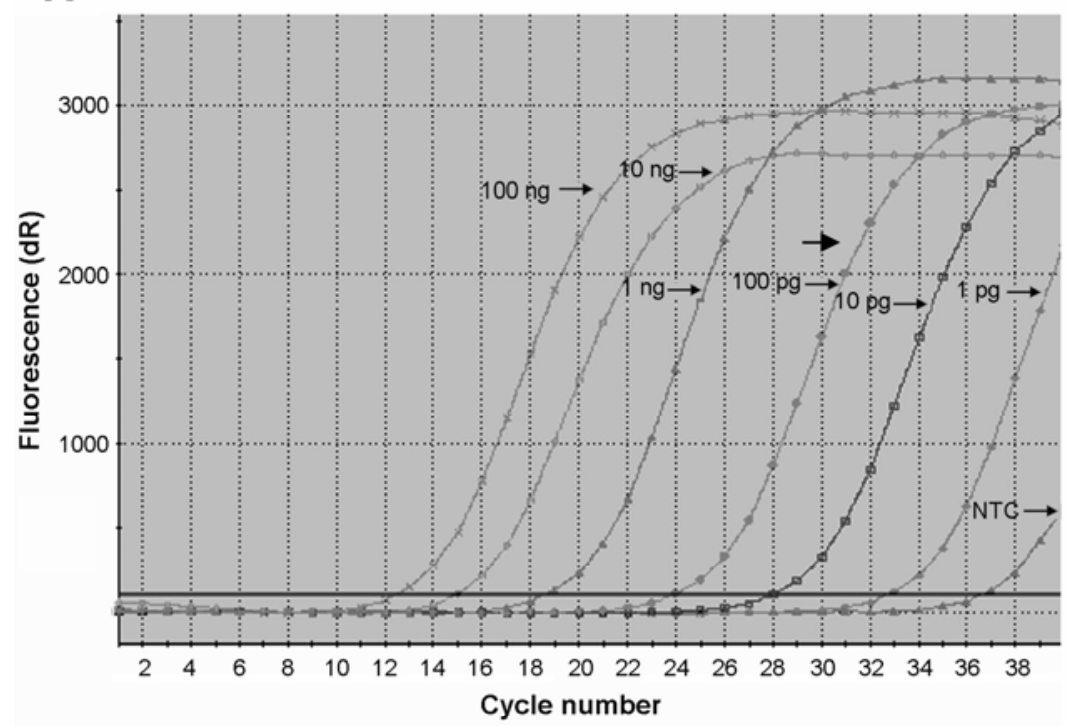

B

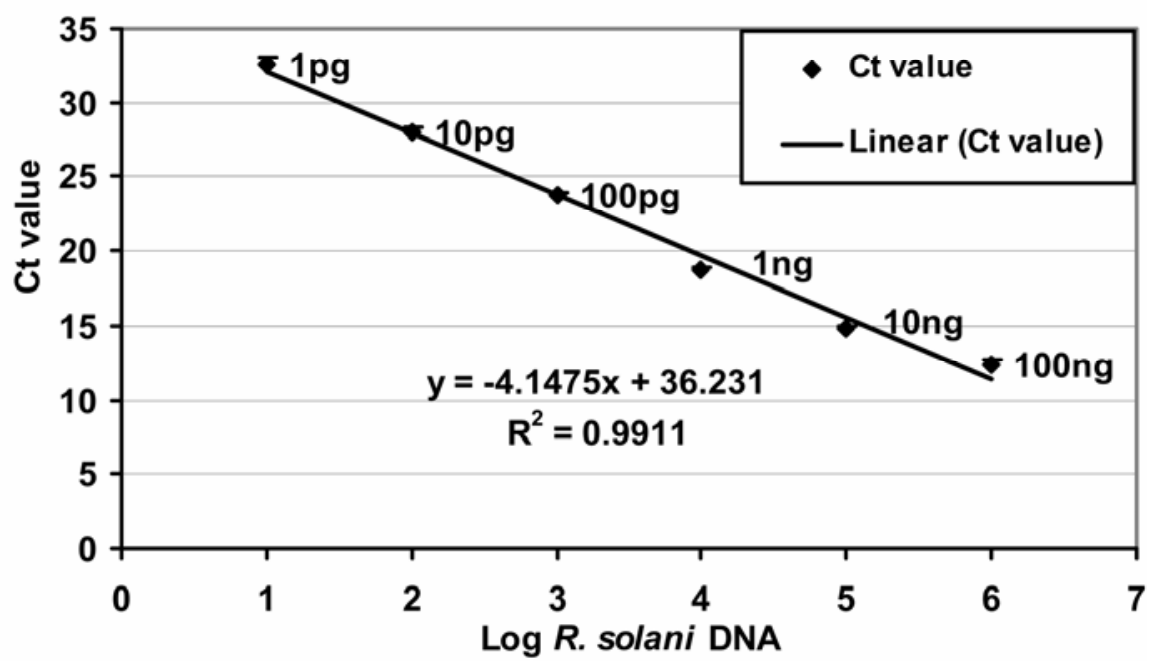

Fig. 3. Rhizoctonia solani DNA dilutions measured by real-time polymerase chain reaction (PCR) cycle threshold $(\mathrm{Ct})$ value. A, Representative real-time PCR fluorescent curves for $R$. solani DNA concentrations from left to right are $100 \mathrm{ng}, 10 \mathrm{ng}, 1 \mathrm{ng}, 100 \mathrm{pg}, 10 \mathrm{pg}, 1 \mathrm{pg}$, and no-template control (NTC). B, Correlation of Ct value to the $\log$ of $R$. solani DNA concentration.
1 pg of pathogen DNA, although dilutions of less than $1 \mathrm{pg}$ were not tested.

Quantification of $R$. solani DNA from infected rice leaves by real-time PCR. Real-time PCR analysis revealed that $R$. solani DNA increased over time as symptoms developed in artificially inoculated rice leaves (data not shown). Fungal growth appeared to follow a sigmoidal curve. The difference between the partially resistant and susceptible cultivars in the detached leaf assay, as determined by visible symptoms, occurred on day 3 post inoculation. Day 3 post inoculation also appeared to be the most appropriate time for measuring disease by real-time PCR quantification of pathogen DNA. Lesions produced by $R$. solani on Nipponbare were more than twofold longer than those on Jasmine 85 (Fig. 4A). Likewise, concentrations of $R$. solani DNA were threefold higher on Nipponbare than on Jasmine 85 (Fig. 4B). Dissociation curve analysis of amplicons produced by real-time PCR revealed two distinct peaks corresponding to the amplicons produced using primers specific to $R$. solani AG-1 IA $\left(79.5^{\circ} \mathrm{C}\right)$ and to the rice ubiquitin gene $\left(81.5^{\circ} \mathrm{C}\right.$ ) (Fig. $4 \mathrm{C})$. The comparison of disease measurements by either lesion length (Fig. 4A) or $R$. solani DNA quantification (Fig. 4B) differentiated resistant Jasmine 85 and susceptible Nipponbare rice cultivars.

\section{DISCUSSION}

Early, rapid, and reliable detection of the sheath blight pathogen, $R$. solani AG-1 IA, will improve the timing and implementation of control measures for the disease, especially fungicide application. Application of fungicides at the initiation of disease may be more effective than after sheath blight has become established, making early detection of the pathogen critical for disease control. Detection of $R$. solani AG-1 IA by the real-time PCR method presented here is both rapid and reliable. The pathogen may be detected in infected rice tissue before fungal structures such as mycelia and sclerotia are visible, and even before disease symptoms appear. Although detection of the sheath blight pathogen by conventional PCR has been reported (17), these primer sequences for $R$. solani are not suitable for real-time PCR because the amplicon they produce is too long. Another advantage of real-time PCR detection is that it can be performed in the field using portable machines, providing the capacity for onsite diagnosis (30), which is not possible with conventional PCR.

Results of this study demonstrate that primers Rs1F and Rs2R are highly specific, amplifying DNA from $R$. solani AG1 IA but not from the most closely related intraspecific group, AG-1 IB, or from the other AG groups of $R$. solani tested here. Although the ITS sequences of AG-1 IB isolates are most similar to those of AG-1 IA (32), sequence alignments further con- 
firm that our primers are specific to AG-1 IA but not to AG-1 IB (Fig. 1). The rDNAITS sequence analysis of $R$. solani AG-1 revealed $99 \%$ sequence identity within AG-1 IA but lower similarity (91 to $95 \%$ ) between subgroups IA, IB, IC, and ID (32). Sequence similarity was even lower for AG-2 1 (89\%) and AG-4 (81\%) (32). Furthermore, the primers do not amplify DNA from the sheath spot pathogen $R$. oryzae or the aggregate sheath spot pathogen $R$. oryzae-sativa, providing evidence for their specificity. Although TaqMan probes offer an additional level of specificity over SYBR green primers alone, the specificity was sufficient (Figs. 1 and 2). In addition, TaqMan probes are more expensive than the SYBR green dye. The primers were specific to the rDNA ITS region sequences representing 80 other $R$. solani AG-1 IA groups from Arkansas, Vietnam, and the Philippines (Fig. 1). Restriction fragment length polymorphism (RFLP) analysis of the genetic diversity of $R$. solani AG-1 IA populations from India and Texas revealed only moderate population subdivision, despite being very distant geographically. The relatively small genetic variation in $R$. solani isolates AG-1 IA detected by ITS sequence (32) and RFLP analysis (20) suggests that the realtime PCR technique described here may be useful for the detection of $R$. solani isolates from a wide geographic area.

Resistance to sheath blight in rice is polygenic, requiring plant breeders to search for QTLs to improve the efficiency of cultivar selection. Locating QTLs for resistance to sheath blight in rice has been a challenging endeavor met with limited success $(18,19,23)$, and many of the reported QTLs remain to be verified by independent studies (23). In fact, one of the main goals of the current multiinstitutional Rice Coordinated Agricultural Project from the United States Department of Agriculture is to identify QTLs for resistance to sheath blight (http://www.uark. edu/ua/ricecap/). Identification of QTLs for resistance to sheath blight has been difficult because of the variation in disease pressure between locations and years, variation in the visual rating of disease between scientists, and variation in experimental conditions between different studies. Quantification of $R$. solani DNA in infested rice tissue by real-time PCR may provide breeders and other researchers with an unbiased method for measuring fungal growth in rice plants. The use of primers specific to the rice ubiquitin gene allows the user to employ relative QPCR, often used in gene expression studies (25), in addition to the absolute QPCR presented in this study. The ubiquitin primers also allow the user to compare the accuracy of DNA quantification levels determined spectrophotometrically to the $\mathrm{Ct}$ values obtained by QPCR. The analysis of amplicon dissociation temperature generates additional evidence for primer specificity. Real-time PCR accurately quantified pathogen DNA in numerous other systems $(8,14,31,33,34,38)$, including the Mag- naporthe grisea in the rice-rice blast interaction (24). In summary, the real-time PCR technique described here may be applicable for detecting and quantifying $R$. solani

A

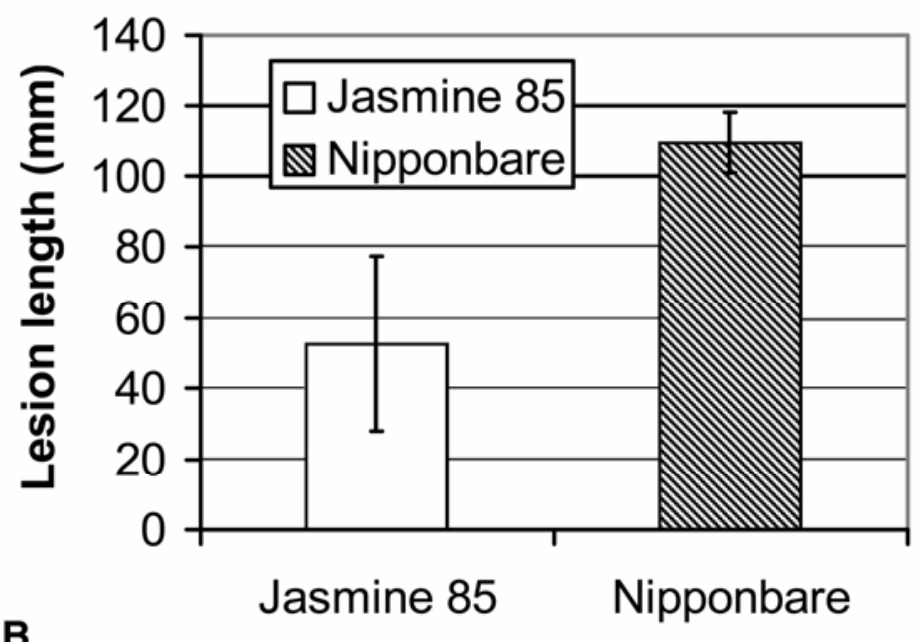

B
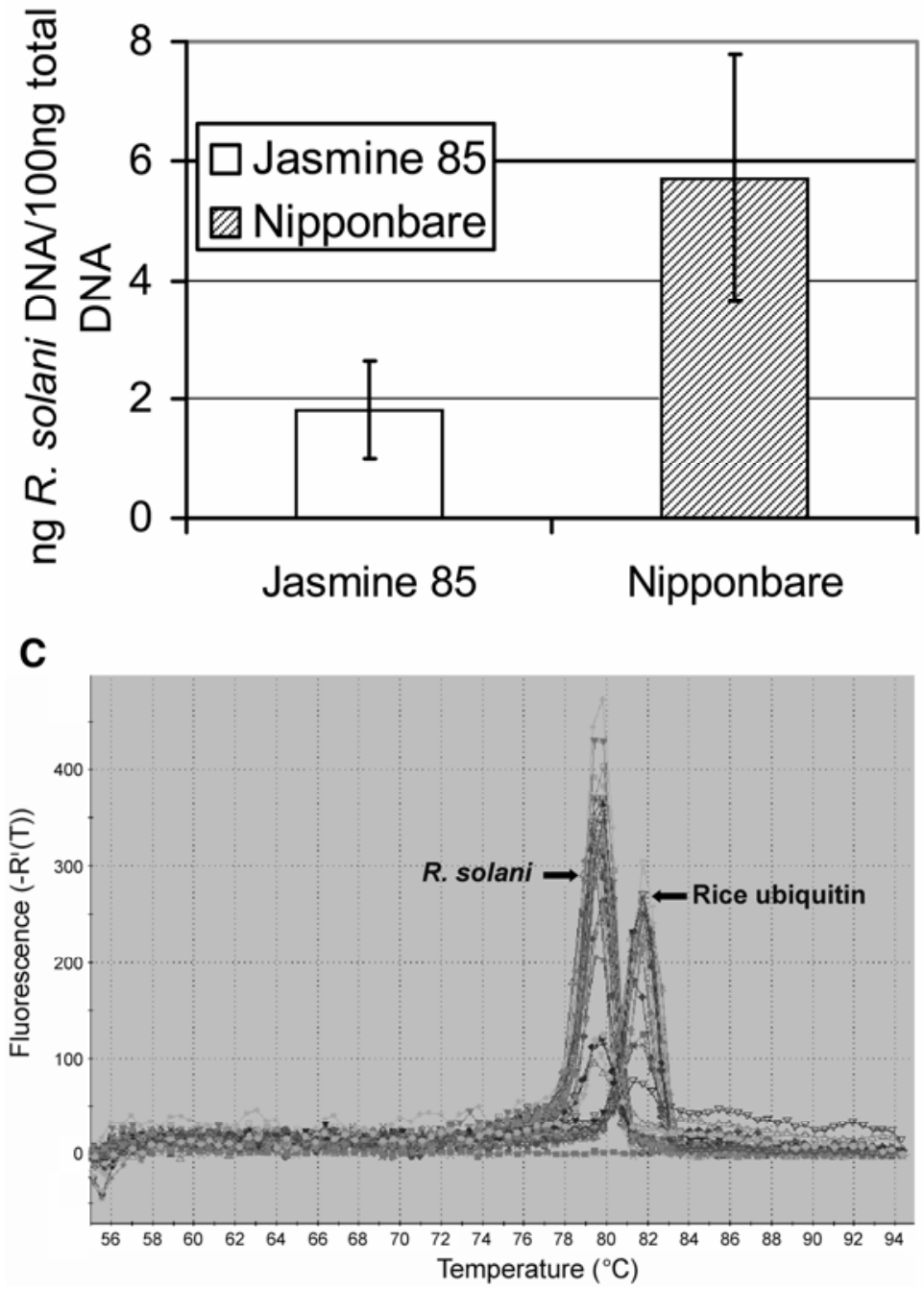

Fig. 4. Quantification of Rhizoctonia solani infection of detached rice leaves 3 days after pathogen inoculation on a moderately resistant cultivar (Jasmine 85) and a susceptible cultivar (Nipponbare). A, Mean lesion length caused by $R$. solani. B, Quantification of $R$. solani DNA by real-time polymerase chain reaction from $100 \mathrm{ng}$ of total DNA extracted from the same rice leaves. Variation among three biological replications is represented by the standard error of the mean. C, Dissociation curve analysis of amplicons produced by $R$. solani primers Rs $1 \mathrm{~F}$ and Rs $2 \mathrm{R}$ and rice ubiquitin primers RUBQF and RUBQR. 
AG-1 IA isolates from around the world, improving disease control and providing an unbiased method for quantifying $R$. solani growth in rice plants.

\section{ACKNOWLEDGMENTS}

This work was supported in part by the multiinstitutional USDA/NRI Rice Coordinated Agricultural Project grant (2004-35317-14867). We thank Y. Jia for providing numerous $R$. solani isolates and rDNA ITS sequences, and C. Rothrock for additional $R$. solani isolates as well as $R$. oryzae and $R$. oryzae sativa isolates.

\section{LITERATURE CITED}

1. Altschul, S. F., Gish, W., Miller, W., Myers, E. W., and Lipman, D. J. 1990. Basic local alignment search tool. J. Mol. Biol. 215:403-410.

2. Bach, H. J., Jessen, I., Schloter, M., and Munch, J. C. 2003. A TaqMan-PCR protocol for quantification and identification of the phytopathogenic Clavibacter michiganensis subspecies. J. Microb. Methods 52:85-91.

3. Balaji, B., Bucholtz, D. B., and Anderson, J. M. 2003. Barley yellow dwarf virus and cereal yellow dwarf virus quantification by real-time polymerase chain reaction in resistant and susceptible plants. Phytopathology 93:1386-1392.

4. Bates, J. B., and Taylor, E. J. A. 2001. Scorpion ARMS primers for SNP real-time PCR detection and quantification of Pyrenophora teres. Mol. Plant Pathol. 2:275-280.

5. Bates, J. B., Taylor, E. J. A, Kenyon, D. M., and Thomas, J. E. 2001. The application of real-time PCR to the identification, detection and quantification of Pyrenophora teres. Mol. Plant Pathol. 2:49-57.

6. Belmar, S. B., Jones, R. K., and Starr, J. L. 1987. Influence of crop rotation on inoculation density of Rhizoctonia solani and sheath blight incidence in rice. Phytopathology 77:11381143.

7. Bertolini, E., Olmos, A., López, M. M., and Cambra, M. 2003. Multiplex nested reverse transcription-polymerase chain reaction in a single tube for sensitive and simultaneous detection of four RNA viruses and Pseudomonas savastanoi pv. savastanoi in olive trees. Phytopathology 93:286-292.

8. Böhm, J., Hahn, A., Schubert, R., Bahnweg, G., Adler, N., Nechwatal, J., Oehlmann, R., and Oiwald, W. 1999. Real-time quantitative PCR: DNA determination in isolated spores of the mycorrhizal fungus Glomus mosseae and monitoring of Phytophthora infestans and Phytophthora citricola in their respective host plants. J. Phytopathol. 409-416.

9. Eizenga, G. C., Lee, F. N., and Rutger, J. N. 2002. Screening Oryza species plants for rice sheath blight resistance. Plant Dis. 86:808-812.

10. Eun, A. J. C., Seol, M. L., and Wong, S. M. 2000. Simultaneous quantitation of two orchard viruses by the TaqMan real-time RTPCR. J. Virol. Methods 87:151-160.

11. Filion, M., St.-Arnaud, M., and Jabaji-Hare, S. H. 2003. Direct quantification of fungal DNA from soil substrate using real-time PCR. J. Microb. Methods 53:67-76.

12. Filion, M., St.-Arnaud, M., and Jabaji-Hare,
S. H. 2003. Quantification of Fusarium solani f. sp. phaseoli in mycorrhizal ban plants and surrounding mycorrhizosphere soil using realtime polymerase chain reaction and direct isolations on selective media. Phytopathology 93:229-235.

13. Fraaije, B. A., Butters, J. A., Coelho, J. M., Jones, D. R., and Hollomon, D. W. 2003. Following the dynamics of strobilourin resistance in Blumeria graminis f. sp. tritici using quantitative allele-specific real-time PCR measurements with the fluorescent dye SYBR Green. Plant Pathol. 51:45-54.

14. Gao, X., Jackson, T. A., Lambert, K. N., Li, S., Hartman, G. L., and Niblack, T. L. 2004. Detection and quantification of Fusarium solani f. sp. glycines in soybean roots with real-time quantitative polymerase chain reaction. Plant Dis. 88:1372-1380.

15. Harmon, P. F., Dunkle, L. D., and Latin, R. 2003. A rapid PCR-based method for the detection of Magnaporthe oryzae from infected perennial ryegrass. Plant Dis. 87:1072-1076.

16. Hashiba, T. 1984. Estimating method of severity and yield loss by rice sheath blight disease. Bull. Hokuriku Nat. Agric. Stn. 26:115-164.

17. Johanson, A., Turner, H. C., McKay, G. J., and Brown, A. E. 1998. A PCR-based method to distinguish fungi of the rice sheath-blight complex, Rhizoctonia solani, $R$. oryzae and $R$. oryzae-sativae. FEMS Microbiol. Lett. 162: 289-294.

18. Li, Z., Pinson, S. R. M., Marchetti, M. A., Stansel, J. W., and Park, W. D. 1995. Characterization of quantitative trait loci (QTLs) contributing to field resistance to sheath blight (Rhizoctonia solani). Theor. Appl. Genet. 91:382-388.

19. Li, Z., Pinson, S. R. M., Stansel, J. W., and Park, W. D. 1995. Identification of quantitative trait loci (QTLs) for heading date and plant height in cultivated rice (Oryza sativa L.). Theor. Appl. Genet. 91:374-381.

20. Linde, C. C., Zala, M., Paulraj, R. S. D., McDonald, B. A., and Gnanamanickam, S. S. 2005. Population structure of the rice sheath blight pathogen Rhizoctonia solani AG-1 IA from India. Eur. J. Plant Pathol. 112:113-121.

21. Oliveirira, A. C., Vallim, M. A., Seminghini, C. P., Ar, W. L., Araújo, W. L., Goldman, G. H., and Machado., M. A. 2002. Quantification of Xylella fastidiosa from citrus trees by real-time polymerase chain reaction assay. Phytopathology 92:1048-1054.

22. Pan, X. B., Rush, M. C., Sha, X. Y., Xie, Q. J., Stetina, S. D., and Oard, J. H. 1999. Major gene, nonallelic sheath blight resistance from the rice cultivars 'Jamine 85 ' and 'Tequing.' Crop Sci. 39:338-346.

23. Pinson, S. R. M., Capdevielle, F. M., and Oard, J. H. 2005. Confirming QTLs and finding additional loci conditioning sheath blight resistance in rice using recombinant inbred lines. Crop Sci. 45:503-510.

24. Qi, M., and Yang, Y. 2002. Quantification of Magnaporthe grisea during infection of rice plants using real-time polymerase chain reaction and northern blot/phosphoimaging analyses. Phytopathology 92:870-876.

25. Reyna, N. S., and Yang, Y. 2006. Molecular analysis of the rice MAP kinase gene family in relation to Magnaporthe grisea infection. Mol. Plant-Microbe Interact. 19:530-540.

26. Rodrigues, F. A., Datnoff, L. E., Korndorfer, G. H., Seebold, K. W., and Rush, M. C. 2001 Effect of silicon and host resistance on sheath blight in rice. Plant Dis. 85:827-832.

27. Roy, A. K. 1996. Innovative methods to manage sheath blight of rice. J. Mycopathol. Res. 34:13-19

28. Rush, M. C., and Lee, F. N. 1992. Sheath blight. Pages 22-23 in: Compendium of Rice Diseases. R. K. Webster and P. S. Gunnell, ed. The American Phytopathology Society, St. Paul, MN.

29. Sayler, R. J., Cartwright, R. D., and Yang, Y. 2006. Genetic characterization and real-time PCR detection of Burkholderia glumae, a newly emerging bacterial pathogen of rice in the United States. Plant Dis. 90:603-610.

30. Schaad, N. W., Opgenorth, D., and Gaush, P. 2002. Real-time polymerase chain reaction for one-hour on-site diagnosis of Pierce's disease of grape in early season asymptomatic vines. Phytopathology 92:721-728.

31. Schena, L., Nigro, F., Ippolito, A., and Gallitelli, D. 2004. Real-time quantitative PCR: a new technology to detect and study phytopathogenic and antagonistic fungi. Eur. J. Plant Pathol. 110:893-908.

32. Toda, T., Mghalu, J. M., Priyatomojo, A., and Hyakumachi, M. 2004. Comparison of sequences for the internal transcribed spacer region in Rhizoctonia solani AG 1-ID and other subgroups of AG 1. J. Gen. Plant. Pathol. 70:270-272.

33. Valsesia, G., Gobbin, D., Patocchi, A., Vecchione, A., Pertot, I., and Gessler., C. 2005. Development of a high-throughput method for quantification of Plasmopara viticola DNA in grapevine leaves by means of quantitative realtime polymerase chain reaction. Phytopathology 95:672-678.

34. Vandemark, G. J., Barker, B. M., and Gritsenko, M. A. 2002. Quantifying Aphanomyces euteiches in alfalfa with a fluorescent polymerase chain reaction assay. Phytopathology 92:265-272.

35. Wang, J., Jiang, J., and Oard, J. H. 2000. Structure, expression and promoter activity of two polyubiquitin genes from rice (Oryza sativa L.). Plant Sci. 156:201-211.

36. Weller, S. A., Elphinstone, J. G., Smith, N. C., Boonham, N., and Stead, D. E. 2000. Detection of Ralstonia solanacearum strains with a quantitative, multiplex, real-time, fluorogenic PCR (TaqMan) assay. Appl. Environ. Microbiol. 66:2853-2858.

37. Willocquet, L., Elazegui, F. A., Castilla, N., Fernandez, L., Fischer, K. S., Peng, S., Teng, P. S., Srivastava, R. K., Singh, H. M., Zhu, D., and Savary, S. 2004. Research priorities for rice pest management in tropical Asia: a simulation analysis of yield losses and management efficiencies. Phytopathology 94:672-682.

38. Winton, L. M., Stone, J. K., Watrud, L. S., and Hansen, E. M. 2002. Simultaneous one-tube quantification of host and pathogen DNA with real-time polymerase chain reaction. Phytopathology 92:112-116. 